\title{
HYDROCHEMICAL CHARACTERISTICS OF THE GALLIKOS RIVER WATER, PREFECTURE OF KILKIS, GREECE
}

\author{
C. MATTAS ${ }^{1}$ \\ G. SOULIOS ${ }^{1}$ \\ A. PANAGOPOULOS ${ }^{2}$ \\ K. VOUDOURIS ${ }^{1, *}$ \\ A. PANORAS ${ }^{2}$
}

Received: 03/12/06

Accepted: 02/04/07
${ }^{1}$ Aristotle University of Thessaloniki, Dept. of Geology University Campus, 541 24, Thessaloniki, Greece

${ }^{2}$ N.AG.RE.F., Land Reclamation Institute 57400, Sindos, Greece

*to whom all correspondence should be addressed: e-mail: kvoudour@geo.auth.gr

\begin{abstract}
The Gallikos river basin is located in the northern part of Greece and discharges into the Thermaikos Gulf, North Aegean sea. Three main tributaries contribute to the river, the basin of which has a total areal extent of $930 \mathrm{~km}^{2}$. The basin of Gallikos river is formed of metamorphic rocks, limestones, Neogene and Quaternary deposits. Groundwater resources are mainly located within the carbonate rocks and the quaternary deposits.

Water quality deterioration is documented based on the performed hydrochemical analyses of samples collected along the river course and its tributaries during the end of the wet and the dry seasons of year 2004. Results were correlated to the groundwater quality as this is reflected by analyses conducted on samples collected from wells adjacent to the river over the same periods. Samples were analyzed for major ions, nitrates, $\mathrm{BOD}_{5}, \mathrm{COD}$, heavy metals and boron, whilst in situ measurements of $\mathrm{pH}$, electrical conductivity and water temperature were performed.

River water quality is related to the flow regime and is influenced by the geological structure, agricultural activities, as well as by untreated waste effluent that is discharged from villages and small industrial units that are scattered along the river basin.
\end{abstract}

KEYWORDS: Hydrochemistry, surface water, groundwater, water quality, Greece.

\section{INTRODUCTION}

Water quality of the Gallikos river is influenced by the geological structure, agricultural activities, as well as by untreated waste effluent that is discharged from the town of Kilkis and numerous villages and industrial units spread along the river basin. Water quality deterioration has been recorded in the last decades in many rivers of Greece, due to human activities. River water seepage is known to considerably contribute to groundwater recharge in several basins and the Gallikos river basin is considered amongst them. Thus, surface water quality affects groundwater quality of the aquifer system that is formed in the basin, which is the main source of potable water.

Geology and hydrogeology of the river basin, as well as the groundwater quality has been examined by previous study (Mattas et al., 2005). It is suggested that the main source of groundwater pollution is the uncontrolled direct discharge of untreated waste effluent into the torrents of the region. Sporadic incidents of nitrate pollution are also documented and attributed to overfertilization, rendering groundwater unsuitable for human consumption.

This work was carried out in the framework of a research project funded by the Greek Ministry of Development (General Secretariat for Research and Technology), and deals with the water quality of the upper part of the Gallikos river basin. Moreover, it aims at proposing a set of actions towards the direction of rational and sustainable management of both surface and groundwater resources in the basin. 


\section{DESCRIPTION OF THE GALLIKOS RIVER BASIN}

The Gallikos river is located in the northern part of Greece; flows through the prefectures of Kilkis and Thessaloniki and discharges into the Thermaikos Gulf, North Aegean Sea. Three main tributaries contribute to the river and the coastal section of the basin is part of a deltaic system (Poulos et al., 2000). The upper part of the basin that forms the study area, covers about $750 \mathrm{~km}^{2}$. A topographic map of the study area depicting the natural hydrologic boundaries is illustrated in Fig. 1.

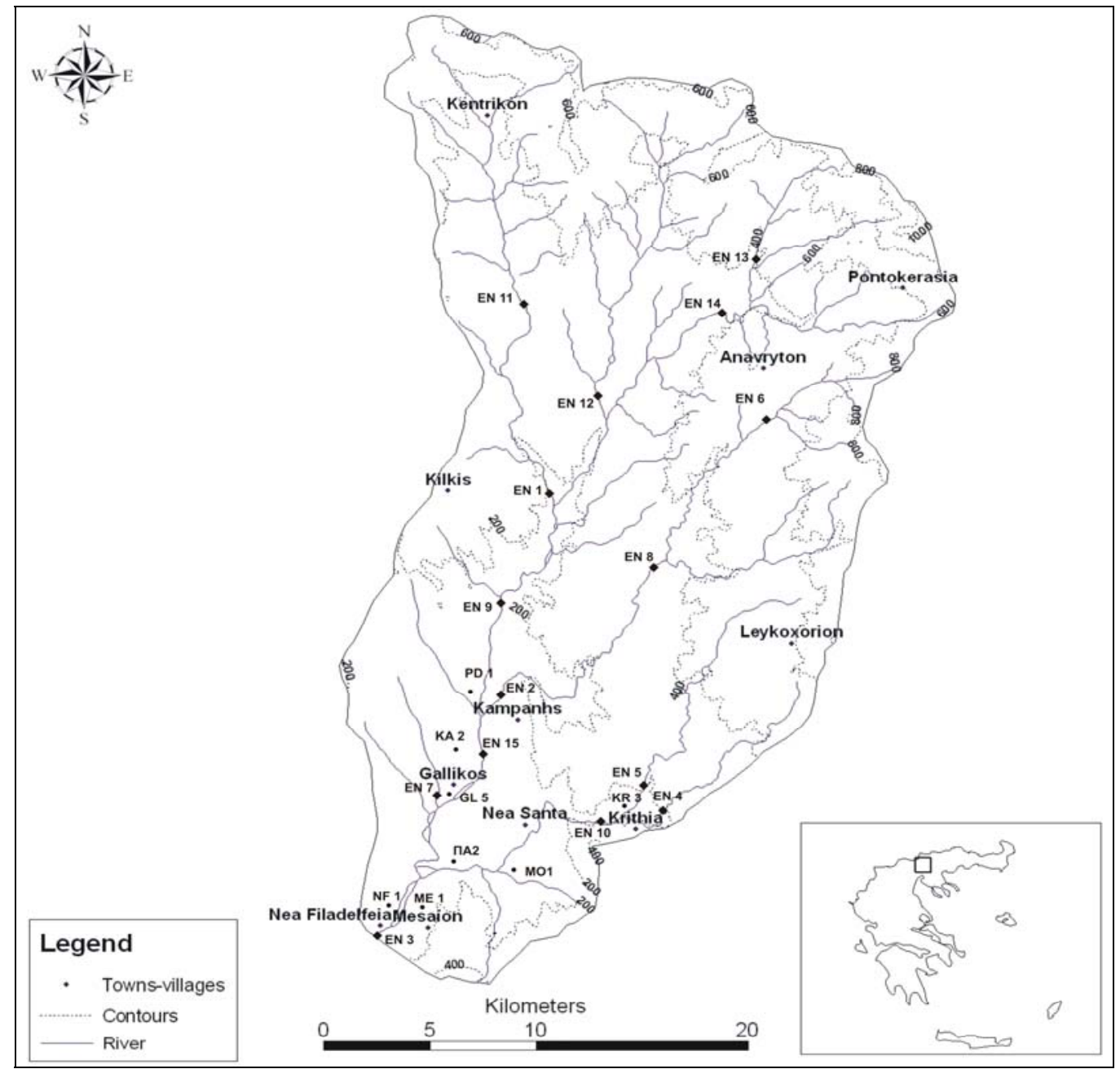

Figure 1. Topographic map of the Gallikos river basin, depicting the sampling sites.

Mean annual rainfall on the basin is $480 \mathrm{~mm}$ and mean annual stream flow is $22 \times 10^{6} \mathrm{~m}^{3}$ at Nea Filadelfia station, during the period 2004-2005 (Table 1). Over about $70 \%$ of the annual rainfall occurs during the wet period from October to May next year.

Seasonal climatic changes have a direct influence on river discharge and weathering processes. The basin of the Gallikos river is mainly formed of metamorphic rocks, Neogene and Quaternary deposits, and a small outcrop of limestones. Groundwater resources are mainly located within the Quaternary deposits and the carbonate rocks. Small villages and industrial units are scattered within the basin. Graze land, cotton and cereal cultivations form the main agricultural land use. Domestic waste effluent systems either do not exist or are not in operation.

\section{DATA COLLECTION AND ANALYSIS}

Sampling took place in the end of wet (May) and dry period (October) of year 2004, as well as in the end of wet period (May) of year 2005. These periods represent the highest and lowest ground and surface water levels respectively thus considered most appropriate to study 
possible hydrochemical variations. Fourteen (14) sampling sites have been selected along the course of the river and its tributaries (Fig. 1). Water samples were collected from the middle of the riverbed and shipped chilled to the laboratory in an appropriate isothermal, box. Samples collected for determination of heavy metals were filtered in situ through $45 \mu \mathrm{m}$ filters and treated with $\mathrm{HNO}_{3}{ }^{-}$.

Table 1. General characteristics of the Gallikos River upper part (as illustrated in Fig. 1)

\begin{tabular}{lr}
\hline Catchment area $\left(\mathrm{km}^{2}\right)$ & 750.0 \\
Total river length $(\mathrm{km})$ & 43.0 \\
Mean altitude $(\mathrm{m})$ & 337.5 \\
Maximum altitude $(\mathrm{m})$ & 1180.0 \\
Mean annual rainfall $(\mathrm{mm})$ & 480.0 \\
Mean annual temperature $\left({ }^{\circ} \mathrm{C}\right)$ & 16.5 \\
Mean annual discharge $\left(\mathrm{I} \mathrm{s}^{-1}\right)$ & 700.0 \\
\hline
\end{tabular}

Furthermore, eight groundwater samples from existing shallow wells near the river were collected, in order to study groundwater quality and correlate it to surface water. In situ measurements of pH, Electrical Conductivity (E.C.), Dissolved Oxygen (D.O.) and water temperature were also taken. Samples were analyzed in the Laboratory of the Land Reclamation Institute (National Agricultural Research Foundation), and the following parameters were determined: $\mathrm{Ca}^{2+}, \mathrm{Mg}^{2+}, \mathrm{Na}^{+}, \mathrm{K}^{+}, \mathrm{Cl}^{-}, \mathrm{NO}_{3}{ }^{-}, \mathrm{NO}_{2}^{-}, \mathrm{SO}_{4}{ }^{2-}, \mathrm{B}$ and $\mathrm{HCO}_{3}{ }^{-} . \mathrm{Na}^{+}$ and $\mathrm{K}^{+}$were measured by flame photometry; $\mathrm{Ca}^{2+}, \mathrm{Mg}^{2+}, \mathrm{Cl}^{-}$, and $\mathrm{HCO}_{3}^{-}$were determined by titration; $\mathrm{NO}_{3}^{-}, \mathrm{NO}_{2}^{-}, \mathrm{B}$ and $\mathrm{SO}_{4}{ }^{2-}$ were measured by spectrophotometry. Heavy metals $\mathrm{Fe}$, $\mathrm{Mn}, \mathrm{Cu}, \mathrm{Pb}, \mathrm{Cd}, \mathrm{Zn}$ were measured by atomic absorption (Stamatis et al., 2001). Finally, $\mathrm{BOD}_{5}$ and COD were determined in the Laboratory of the Thessaloniki Water Supply and Sewerage Company (EYATH). Mean values of the hydrochemical analyses results are listed in Tables 2 \& 3.

Also, data from previous hydrochemical studies (Kouimtzis, 2001; Soulios et al., 2001), as well as data provided by the Greek Ministry of Agriculture were considered, in order to compare the results. Furthermore, conventional hydrochemical techniques were applied to study groundwater quality and classify the water samples. AquaChem v.5.0 software by Waterloo Hydrogeologic Inc., was utilised for data processing, archiving and the production of hydrochemical plots. Hydrochemical sections were drawn for the examination of major ion variations along the river course.

Monthly river discharge measurements were used in order to correlate runoff to water quality. The location of the discharge measurement stations (EN3, EN9, EN10) is illustrated in Fig. 1. River discharge measurements $\left(\mathrm{I} \mathrm{s}^{-1}\right)$ at 3 stations during the period 2004-2005 are shown in Fig. 2. Mean discharge value is $700 \mathrm{I} \mathrm{s}^{-1}$ at Nea Filadelfia station (EN3). Considerable seasonal discharge fluctuations are noticeable and high discharge values have been recorded during the wintertime.

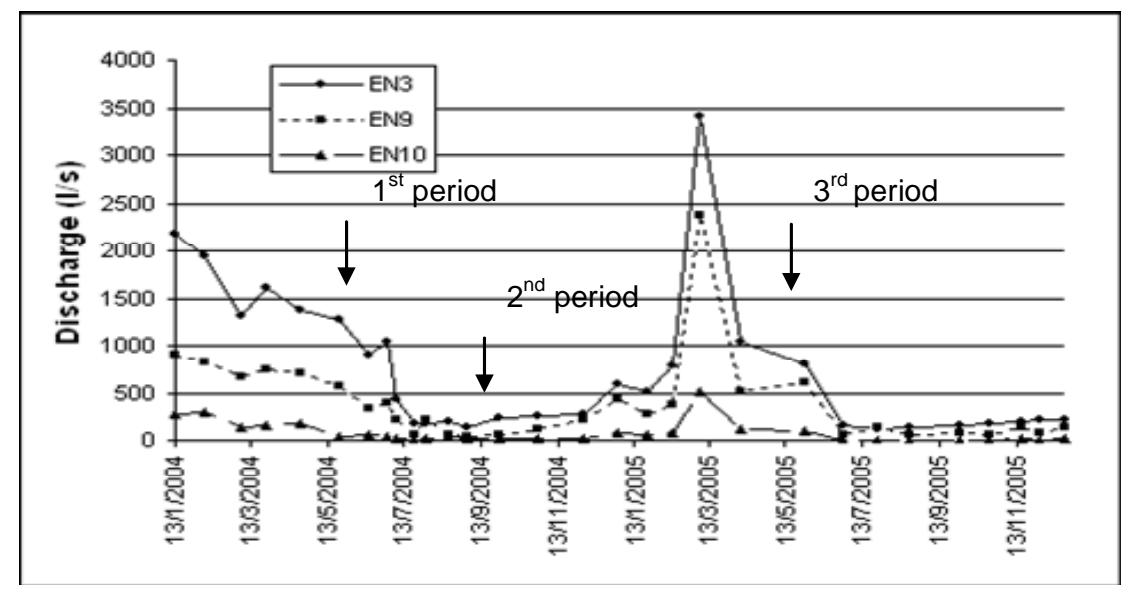

Figure 2. River discharge $\left(\mathrm{I} \mathrm{s}^{-1}\right)$ at the 3 monitoring stations (as depicted in Fig. 1) 
Table 2. Summary statistical results (mean values) of chemical analyses of surface water. Concentration in mg I' E.C. in $\mu \mathrm{S} \mathrm{cm}{ }^{-1}$

\begin{tabular}{|c|c|c|c|c|c|c|c|c|c|c|c|c|c|c|}
\hline $\begin{array}{c}\text { Sampling } \\
\text { point }\end{array}$ & $\mathrm{pH}$ & E.C. & $\mathrm{T}\left({ }^{\circ} \mathrm{C}\right)$ & $\mathrm{Na}^{+}$ & $\mathrm{K}^{+}$ & $\mathrm{Mg}^{2+}$ & $\mathrm{Ca}^{2+}$ & $\mathrm{Cl}^{-}$ & $\mathrm{SO}_{4}{ }^{2-}$ & $\mathrm{NO}_{3}^{-}$ & $\mathrm{HCO}_{3}^{-}$ & $\mathrm{CO}_{3}{ }^{2-}$ & D.O. & $\mathrm{O}_{2}(\%)$ \\
\hline EN1 & 7.75 & 807 & 15.8 & 44.0 & 6.2 & 33.5 & 75.1 & 42.6 & 45.0 & 15.5 & 360.0 & 45.6 & 9.7 & 96.8 \\
\hline EN2 & 7.90 & 684 & 15.9 & 39.7 & 4.5 & 30.4 & 77.4 & 46.1 & 48.2 & 9.1 & 337.6 & 26.4 & 11.1 & 116.0 \\
\hline EN3 & 7.94 & 1545 & 15.2 & 145 & 5.8 & 45.5 & 121.8 & 263.6 & 75.4 & 18.2 & 368.1 & 56.4 & 10.3 & 104.0 \\
\hline EN4 & 8.25 & 525 & 15.4 & 51.7 & 3.0 & 42.0 & 68.5 & 61.5 & 73.6 & 2.8 & 307.1 & 52.0 & 12.5 & 131.5 \\
\hline EN5 & 8.24 & 572 & 14.4 & 38.7 & 2.8 & 33.6 & 49.3 & 37.8 & 58.0 & 1.0 & 294.9 & 40.0 & 10.4 & 106.0 \\
\hline EN6 & 8.41 & 554 & 14.9 & 24.3 & 3.5 & 28.4 & 54.7 & 30.8 & 30.8 & 8.7 & 258.6 & 52.0 & 13.3 & 136.7 \\
\hline EN7* & 7.89 & 1760 & 10.0 & 180.0 & 5.8 & 55.0 & 110.0 & 280.5 & 25.6 & 20.3 & 536.8 & 79.2 & 9.1 & 82.0 \\
\hline EN8 & 8.35 & 561 & 16.0 & 32.5 & 5.0 & 22.9 & 51.7 & 35.5 & 24.4 & 4.1 & 283.8 & 36.0 & 14.1 & 147.5 \\
\hline EN9 & 7.86 & 906 & 17.0 & 56.3 & 11.9 & 37.6 & 82.4 & 65.1 & 59.1 & 6.9 & 425.1 & 40.0 & 4.7 & 46.3 \\
\hline EN10 & 7.95 & 685 & 14.5 & 48.3 & 2.2 & 35.5 & 61.2 & 48.5 & 39.6 & 9.3 & 327.4 & 50.0 & 9.6 & 100.0 \\
\hline EN11 & 8.06 & 734 & 18.2 & 36.5 & 3.7 & 33.4 & 75.0 & 42.6 & 45.6 & 8.9 & 302.0 & 39.6 & 11.7 & 123.5 \\
\hline EN12 & 8.32 & 728 & 15.4 & 31.7 & 5.2 & 41.7 & 63.0 & 39.2 & 64.5 & 21.0 & 317.2 & 43.2 & 11.7 & 117.2 \\
\hline EN13 & 8.37 & 619 & 16.1 & 21.0 & 3.6 & 38.1 & 55.2 & 27.2 & 63.5 & 11.6 & 280.7 & 42.4 & 10.5 & 104.3 \\
\hline EN14 & 8.45 & 667 & 16.0 & 23.7 & 5.8 & 38.8 & 72.1 & 30.8 & 67.8 & 12.1 & 252.2 & 57.6 & 12.0 & 122.7 \\
\hline EN15** & 8.37 & 700 & 25.0 & 50.0 & 5.5 & 38.9 & 56.1 & 56.8 & 65.7 & 2.2 & 305.1 & 18.0 & 11.2 & 130.0 \\
\hline
\end{tabular}

${ }^{\star}$ Results from period May 2004. ${ }^{\star \star}$ Mean values from periods September 2004 and May 2005.

Table 3. Summary statistical results (mean values) of chemical analyses of groundwater. Concentration in mg ${ }^{-1}$, E.C. in $\mu \mathrm{S} \mathrm{cm}{ }^{-1}$

\begin{tabular}{|c|c|c|c|c|c|c|c|c|c|c|c|c|c|c|}
\hline $\begin{array}{l}\text { Sampling } \\
\text { point }\end{array}$ & $\mathrm{pH}$ & E.C. & $\mathrm{T}\left({ }^{\circ} \mathrm{C}\right)$ & $\mathrm{Na}^{+}$ & $\mathrm{K}^{+}$ & $\mathrm{Mg}^{2+}$ & $\mathrm{Ca}^{2+}$ & $\mathrm{Cl}^{-}$ & $\mathrm{SO}_{4}{ }^{2-}$ & $\mathrm{NO}_{3}^{-}$ & $\mathrm{HCO}_{3}^{-}$ & $\mathrm{CO}_{3}{ }^{2-}$ & D.O. & $\mathrm{O}_{2}(\%)$ \\
\hline MO1 & 7.3 & 859 & 17.0 & 30.3 & 12.6 & 28.3 & 136.7 & 81.7 & 39.2 & 52.5 & 398.6 & 0 & 8.4 & 90.8 \\
\hline PA2 & 7.4 & 3170 & 17.5 & 246.7 & 6.6 & 102.6 & 288.9 & 764.4 & 122.3 & 57.9 & 435.2 & 6 & 4.9 & 50.4 \\
\hline KA2 & 7.1 & 914 & 17.9 & 45.7 & 12.9 & 29.2 & 105.7 & 49.7 & 38.6 & 12.2 & 483.9 & 0 & 6.5 & 70.5 \\
\hline KR3 & 7.5 & 508 & 18.0 & 36.1 & 10.1 & 18.7 & 35.2 & 42.6 & 23.4 & 7.2 & 288.9 & 0 & 6.2 & 68.0 \\
\hline ME1 & 7.3 & 1417 & 17.2 & 68.0 & 18.4 & 57.0 & 156.0 & 189.0 & 82.8 & 70.5 & 459.7 & 0 & 4.0 & 41.1 \\
\hline NF1 & 7.3 & 1330 & 15.4 & 91.3 & 16.1 & 43.7 & 130.0 & 201.0 & 54.8 & 18.9 & 390.6 & 0 & 4.5 & 46.2 \\
\hline PD1 & 7.3 & 829 & 17.3 & 49.7 & 18.7 & 36.2 & 85.7 & 62.7 & 31.7 & 1.7 & 410.8 & 0 & 6.9 & 84.8 \\
\hline GL5 & 7.6 & 2337 & 12.5 & 313 & 11.6 & 41.3 & 118.0 & 477.0 & 126.0 & 12.1 & 418.8 & 10 & 6.5 & 68.3 \\
\hline
\end{tabular}




\section{RESULTS}

\section{Surface waters}

Table 2 summarizes the results of chemical analyses of surface water samples. A series of observations and conclusions can be made from the hydrochemical analyses in the Gallikos river:

- The $\mathrm{pH}$ of surface water varies in the range 7.42-9.01 indicating a slightly alkaline type. Electrical conductivity ranges between 495-1743 $\mu \mathrm{S} \mathrm{cm}^{-1}$; the highest values are recorded at Nea Filadelfia sampling point (EN3) and are attributed to anthropogenic pollution. Surface water temperature ranges from 8 to $26^{\circ} \mathrm{C}$, depending on atmospheric temperature fluctuations.

- The composition of the surface water for cations is $\mathrm{Ca}^{2+}>\mathrm{Mg}^{2+}>\mathrm{Na}^{+}>\mathrm{K}^{+}$, except of two sampling points EN3 and EN7, where $\mathrm{Na}^{+}$is the predominant cation, due to industrial pollution.

Sodium concentrations vary from 17 to $220 \mathrm{mg} \mathrm{l}^{-1}$. Potassium concentration values are high (2-16 $\left.\mathrm{mg} \mathrm{l}^{-1}\right)$. Calcium varies from $24-136 \mathrm{mg} \mathrm{l}^{-1}$ and magnesium from $18-68 \mathrm{mg} \mathrm{l}^{-1}$. The $\mathrm{Ca}^{2+}$ and $\mathrm{Mg}^{2+}$ presence reflects the lithology of the river basin.

- The composition of the surface water for anions is $\mathrm{HCO}_{3}{ }^{-}>\mathrm{Cl}^{-}$or $\mathrm{SO}_{4}{ }^{2-}>\mathrm{NO}_{3}{ }^{-}$

Bicarbonates ranges from 214 to $536.8 \mathrm{mg} \mathrm{l}^{-1}$. Sulphates concentrations vary with sampling location in the range 11.1-75.4 $\mathrm{mg} \mathrm{I}^{-1}$, with one high value $135.6 \mathrm{mg} \mathrm{l}^{-1}$ at EN4 sampling point. The strong variability of $\mathrm{SO}_{4}{ }^{2-}$ indicates variable sources e.g. ammonium sulphate fertiliser leachate, oxidation of sulphide and anthropogenic pollution (Bajjaali, 2006).

Chloride concentration varies between $17.8-332 \mathrm{mg} \mathrm{l}^{-1}$ and is strongly correlated to sodium fluctuation (Fig. 3), both exhibiting their peak values at the same sampling points EN3 and EN7 located near Nea Filadelfia (Fig. 4).

Nitrate values are from $0.5-28.5 \mathrm{mg} \mathrm{I}^{-1}$ and nitrate sources are agricultural activities and sewage effluent through seepage from septic tanks (Voudouris et al., 2000). It is pointed out that, both manure and fertilisers are applied at the cultivated crops of the study area. Higher $\mathrm{NO}_{3}{ }^{-}$and $\mathrm{Mg}^{2+}$ concentrations are recorded in dry periods when the discharges are low (Fig. 5).

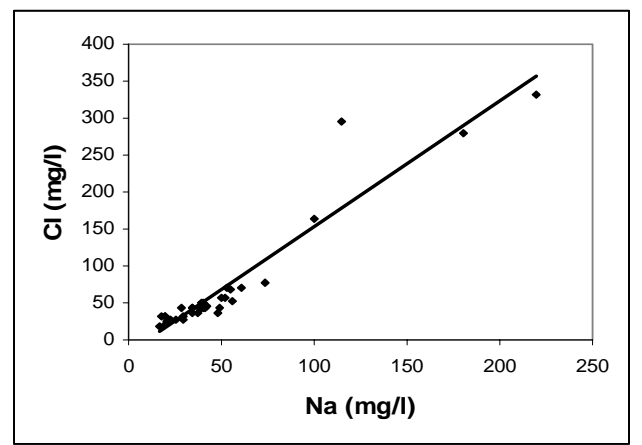

Figure 3. $\mathrm{Na}^{+}-\mathrm{Cl}^{-}$diagram.

- Significant correlation at $\mathrm{p}$-level 0.05 has been obtained between: $\mathrm{Na}^{+}-\mathrm{Cl}^{-}(0.93-0.99)$, $\mathrm{Na}^{+}-\mathrm{Ca}^{2+}(0.82-0.85)$. Correlation coefficients between $\mathrm{SO}_{4}{ }^{2-}-\mathrm{Na}^{+}, \mathrm{Ca}^{2+}-\mathrm{Cl}$, as well as between $\mathrm{K}^{+}-\mathrm{Mg}^{2+}$, range from small to high values, depending on the sampling period.

- Boron concentrations range from 0 to $0.32 \mathrm{mg} \mathrm{I}^{-1}$. Generally, its origin is associated with marine processes, dissolution of evaporites and anthropogenic pollution (Molina et al., 2003), the latter being the most probable source, based on the geological structure of the region.

- Iron (Fe) and manganese (Mn) concentrations are below detection limit (d.I.), which is less than 0.1 and $0.03 \mathrm{mg} \mathrm{l}^{-1}$, respectively, in most of the examined samples. High Fe concentrations $\left(0.5 \mathrm{mg} \mathrm{l}^{-1}\right)$ and $\mathrm{Mn}$ concentrations $\left(0.84 \mathrm{mg} \mathrm{l}^{-1}\right)$ are recorded at samples collected from site EN 9. Likewise, zinc $(\mathrm{Zn})$ concentration in the majority of water 
samples is under $0.05 \mathrm{mg} \mathrm{l}^{-1}$, which is the d.l.; whilst a maximum value of $24 \mathrm{mg} \mathrm{l}^{-1}$ is recorded in a sample located adjacent an industrial area.

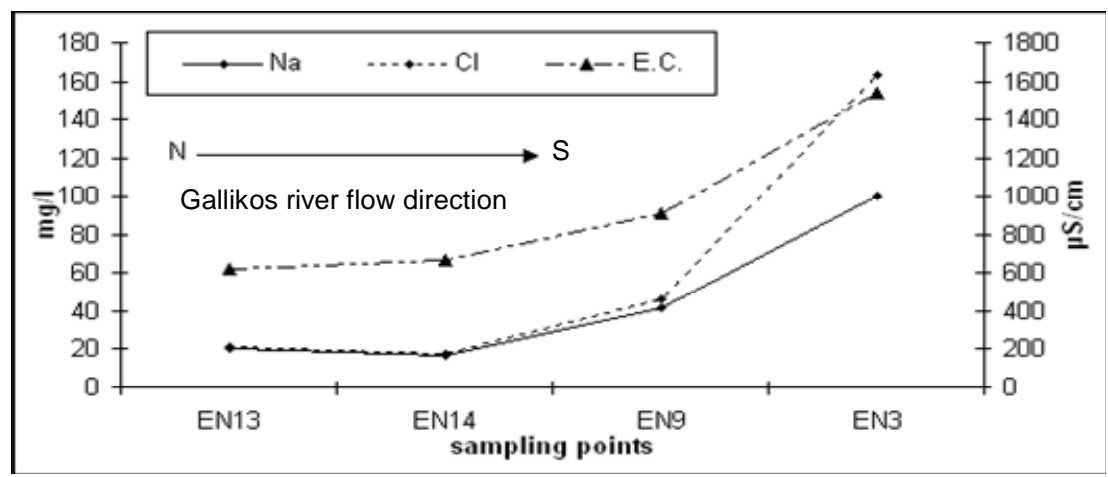

Figure 4. Hydrochemical section along the Gallikos river (May 2004, direction as seen in Fig. 1)

- Dissolved oxygen concentrations are reasonable for potable use, apart from sampling point EN9, near Kolhida village, where the minimum value of $0.35 \mathrm{mg} \mathrm{l}^{-1}$ is recorded. The same situation exists for the oxygen saturation, which ranges from 4-182\%. Oxygen content of the surface water depends mainly on the surface water temperature, but is also highly dependable on its pollution loads. The solubility of oxygen decreases with rising temperatures, however this correlation is not clear, as illustrated in Fig. 6, since data represent different sampling points spread over the extent of the basin, each influenced by numerous factors with respect to the oxygen content. The oxygen undersaturation is recorded at upland river parts and can be attributed to the influence of altitude on the equilibrium concentration (Skoulikidis, 1993).

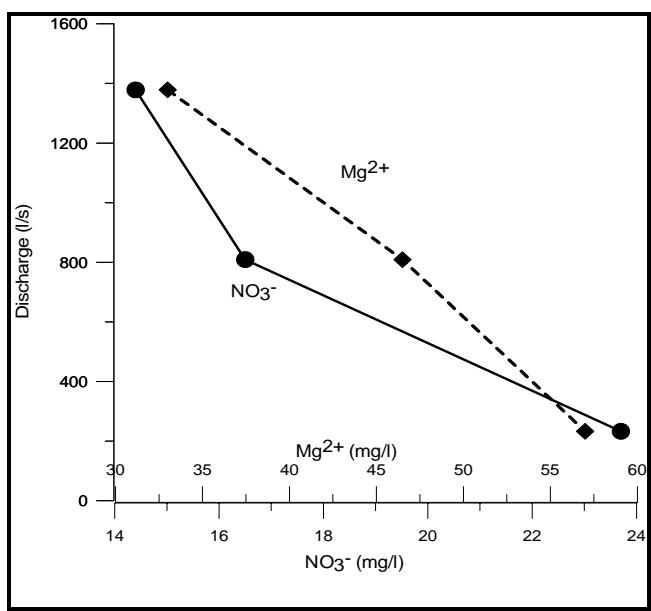

Figure 5. Relation between discharge and $\mathrm{Mg}^{2+}$ and $\mathrm{NO}_{3}{ }^{-}$concentration at sampling point EN3

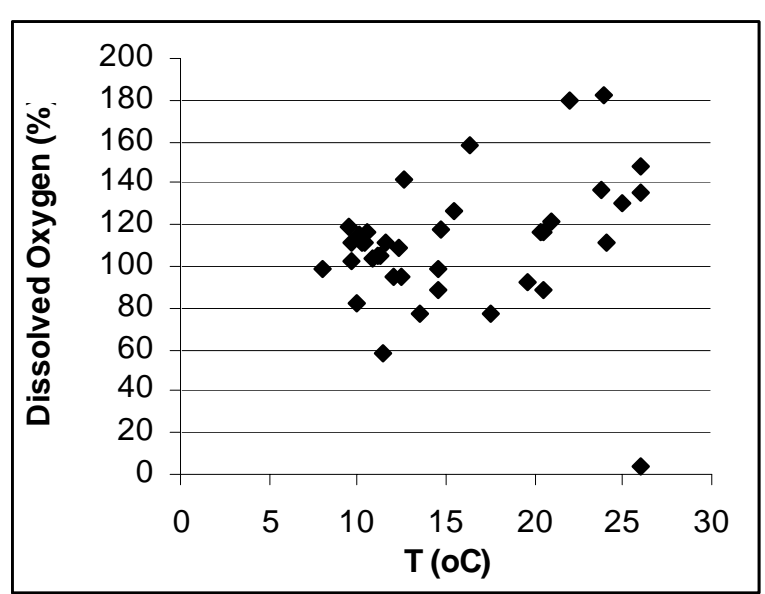

Figure 6. Dissolved oxygen vs temperature

- Significant temporal and spatial variations of the COD (from 0 to $87.1 \mathrm{mg} \mathrm{I}^{-1}$ ) were noted, the highest values being recorded at the Nea Filadelfia area. The majority of the samples have $\mathrm{BOD}_{5}$ values under d.I., which is $2.4-3 \mathrm{mg} \mathrm{l}^{-1}$, depending on the sample quantity. Higher values $\left(6.75 \mathrm{mg} \mathrm{l}^{-1}\right)$ are recorded at sampling point EN9 for the period of May 2005. In general, as river discharge decreases, $\mathrm{BOD}_{5}$ and $\mathrm{COD}$ values increase. It is remarkable however, that for the period of September 2004, which is characterized by low river discharge, the values of COD were zero at all sampling points. This is attributed to the documented riverbed infiltration to the aquifer system, which under low discharge periods results in quite limited migration of the pollutants (Mattas et al., 2005). 


\section{Groundwater}

Analyses were carried out on eight (8) groundwater samples collected from shallow representative boreholes drilled in alluvial deposits and located near the river course. The location of the samples is shown in Figure 1. Table 3 shows the mean values of the chemical parameters of groundwater. The overall precision of the analyses is within $\pm 5 \%$, as indicated from the ionic balance.The purpose of the sampling was to examine the interaction between surface water and groundwater chemistry.

- $\quad$ The $\mathrm{pH}$ values range from 6.86 to 7.96 and Electrical Conductivity from 464 to $3810 \mu \mathrm{S}$ $\mathrm{cm}^{-1}$; the high E.C. values correspond to sampling point PA2 (Panteleimonas), which is located in an agricultural and industrial area. The temperature varies from 12.7-20.6 ${ }^{\circ} \mathrm{C}$.

- Sodium and chloride concentrations exhibit great variability, ranging between 26-340 $\mathrm{mg} \mathrm{l}^{-1}$ and 32-944 $\mathrm{mg} \mathrm{l}^{-1}$, respectively. The highest concentrations are also recorded at sampling point PA2. There is a good correlation between chloride and sodium concentration. Potassium ranges from $0.8-35 \mathrm{mg} \mathrm{l}^{-1}$; the highest values generally reflect the first sampling period of May 2004. Calcium concentrations vary from 16.4 to 308.6 $\mathrm{mg} \mathrm{l}^{-1}$, and magnesium from 15 to116.7 $\mathrm{mg} \mathrm{l}^{-1}$.

- Sulphates range between 8.8 and $159 \mathrm{mg} \mathrm{l}^{-1}$ and nitrates between 0.4 to $79.7 \mathrm{mg} \mathrm{l}^{-1}$ Nitrate concentrations in excess of the maximum admissible concentration of $50 \mathrm{mg} \mathrm{l}^{-1}$ set by EU Council for drinking water (EU, 1998), are documented in several occasions especially in areas where intensive agriculture is applied. These are related to fertilisation and irrigation malpractice (Voudouris et al., 2004). Bicarbonates range from 281 to $488 \mathrm{mg} \mathrm{l}^{-1}$, and carbonates from 0 to $30 \mathrm{mg} \mathrm{l}^{-1}$. Nitrite concentration is low, ranging from 0 to $0.06 \mathrm{mg} \mathrm{l}^{-1}$ and boron from 0 to $0.53 \mathrm{mg} \mathrm{l}^{-1}$.

- Two discrete water types may be distinguished from the study of the constructed Piper diagram: $\mathrm{Ca}(\mathrm{Mg})-\mathrm{HCO}_{3}$ and $\mathrm{Na}-\mathrm{Cl}\left(\mathrm{SO}_{4}\right)$, as illustrated in Figure 7.

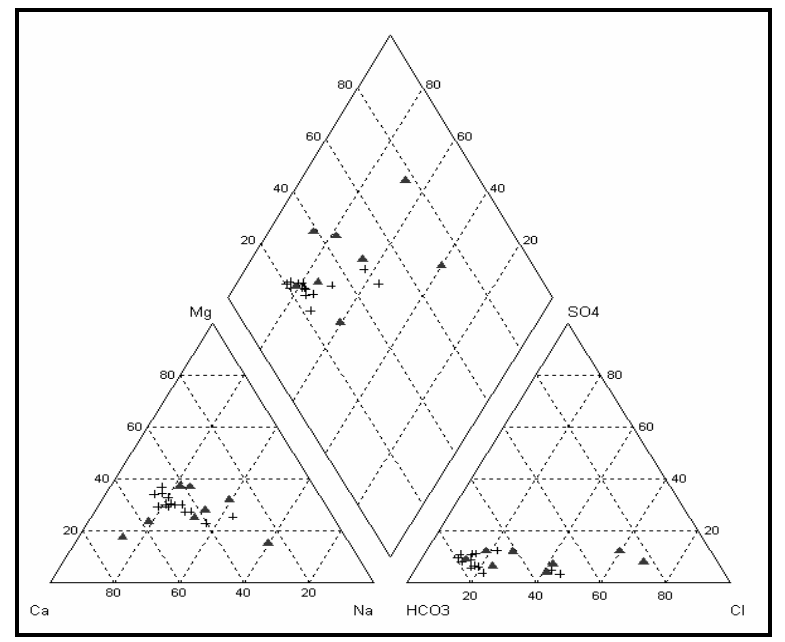

Figure 7. Piper diagram for the period May 2004

(triangle=groundwater, cross=surface water)

- Groundwater collected from shallow boreholes is characterized by relatively low heavy metal concentrations. Thus, iron (Fe) ranges between $0-0.41 \mathrm{mg} \mathrm{l}^{-1}$, zinc ( $\mathrm{Zn}$ ) between $0-0.3 \mathrm{mg} \mathrm{l}^{-1}$ and manganese $(\mathrm{Mn})$ under d.I. in all examined samples. High concentrations of Fe are attributed to lithological conditions of the area (Stamatis et al., 2001; Mattas et al., 2005), and in some cases the values are over the max acceptable limit for drinking water.

- The values of Dissolved Oxygen (D.O.) and Oxygen Saturation (\%), which were determined in situ, are obviously lower than the surface water and in general reduce proportionally to the distance of the wells from the river course. They range from 1.35 to $9.95 \mathrm{mg} \mathrm{l}^{-1}$ for D.O. and from 11 to $96.5 \%$ for Oxygen Saturation. The BOD 5 values are under d.I. of $2.4 \mathrm{mg} \mathrm{l}^{-1}$ and the COD values range from 0 to $9.5 \mathrm{mg} \mathrm{l}^{-1}$, although the majority of the samples has negligible values. 
As previously stated, it is documented (Mattas et al., 2005), that the waters of the Gallikos river infiltrate into the shallow alluvial aquifer, thus influencing groundwater quality. It is therefore suggested and supported by the analysed data, that apart from other existing mechanisms, the uncontrollable discharge of untreated domestic and industrial effluent in the river leads to groundwater quality deterioration.

\section{CONCLUSIONS-DISCUSSION}

The hydrochemical analysis of both surface and groundwater in the Gallikos river basin has provided useful information on water quality. Surface water quality deterioration is apparent and is mainly attributed to anthropogenic pollution. Groundwater samples collected from boreholes drilled near the river are found to be affected by surface water pollution, as river seepage is a main aquifer recharge mechanism.

High river discharge values result in rapid and distant migration of pollutants, at reduced however loads, which creates overall a favorable condition for groundwater quality preservation. On the contrary, it appears that over periods of reduced river discharge, pollution loads are higher although migration is limited. Such conditions though are thought to be favorable of groundwater pollution deterioration, as large proportions of the pollutant loads infiltrate into the saturated zone at specific locations. Plumes may not reach the defined sampling points prior to their infiltration, thus providing a misconception of the system's status. The aforementioned conclusions agree with the results from previous hydrochemical studies in the border area.

Protection of both surface and groundwater would benefit by a dense and appropriately designed systematic water quality monitoring system and by designing and enforcing surface water protection measures such as industrial and domestic effluent treatment plants along the river and its tributaries.

\section{REFERENCES}

Bajjaali W. (2006) Recharge mechanism and hydrochemistry evaluation of groundwater in the Nuaimeh area, Jordan, using environmental isotope techniques, Journal of Hydrogeology, $14,180-191$.

E.U. Council (1998) Council directive 98/83 about water quality intended for human consumption, Official Journal of the European Communities, L330, 32-54.

Kouimtzis T. (2001) Quality of surface water and groundwater in Macedonia region, Proc. of Conf. Hydrogeology and Environment, Hellenic Committee of Hydrogeology, Athens.

Mattas C., Soulios G., Dimopoulos G., Diamantis J., Panagopoulos A., Voudouris K. (2005) Groundwater quality in Gallikos basin, Prefecture of Kilkis, Proc. of $7^{\text {th }}$ Hellenic Conference on Hydrogeology (eds. Stournaras G.), Athens, 311-320.

Molina L., Sanchez-Martos F., Pulido-Bosch A., Vallejos A. (2003) Origin of boron from a complex aquifer in southeast of Spain, Environmental Geology, 44, 301-307.

Poulos S., Chronis G., Collins M., Lykousis V. (2000) Thermaikos Gulf Coastal System, NW Aegean Sea: an overview of water/sediment fluxes in relation to air-land-ocean interactions and human activities, Journal of Marine Systems, 25, 47-76.

Skoulikidis N. (1993) Significance evaluation of factors controlling river water composition, Environmental Geology, 22, 178-185.

Soulios G., Zagana E., Kaklis T., Oikonomidis D. (2001) Hydrochemical surface and underground water data of the upper part of drainage basin of Aliakmon river, Bulletin of the Geological Society of Greece, XXXIVI5, 1959-1966.

Stamatis G, Voudouris K., Karefilakis F. (2001) Groundwater pollution by heavy metals in historical mining area of Lavrio, Attica, Greece, Water, Air, and Soil Pollution, 128, 61-83.

Voudouris K., Panagopoulos A. and Daniil D. (2000) Implications to surface water quality of Korinthos Prefecture from anthropogenic activities, Proc. International Conference Protection and Restoration of the Environment V, (eds. Tsihrintzis A .V., Korfiatis P.G., Katsifarakis L.K., Demetracopoulos C.A .), Thassos, Greece, 2000, 235-242.

Voudouris K., Panagopoulos A. and Koumantakis J. (2004) Nitrate pollution in the coastal aquifer system of the Korinthos Prefecture (Greece), Global NEST: The International Journal, 6(1), 31-38. 